\title{
The impact of agricultural development on karstic groundwater of the Saïda Mountains, Algeria
}

The Mining-Geology-Petroleum Engineering Bulletin UDC: 556.3

DOI: $10.17794 /$ rgn.2019.4.10

Professional paper

\author{
Abdelkader Bentabet'; Habib Azzaz'; Christophe Emblanch²; Benyakhelef Benamina' \\ ${ }^{1}$ Laboratory of Water Science and Technology (LSTE), Faculty of Science and Technology, University of Mustapha Stambouli, Mascara, Algeria \\ ${ }^{2}$ Laboratory of the hydrogeology of Avignon, University of Avignon, France
}

\begin{abstract}
Water quality is a public health issue and this article includes related causes, issues and descriptions for the monitoring of groundwater quality in Algeria. Good water management depends on many qualitative issues, their origin (agriculture), the monitoring of quality and prediction of those parameters during a longer period. The establishment of this work aims at identifying the chemical facies, the origins and the drinking of karstic groundwater of the Saïda Mountains. These mountains are composed of carbonate massifs (limestone-dolomite rocks) of Lower to Middle Jurassic age. They are fed by precipitation and by a relatively dense temporary hydrographic system. The mountains represent an important water reservoir for northwestern Algeria. Anthropogenic impacts have continuously modified the physico-chemical characteristics of the water in this aquifer [ $\left.\mathrm{NO}_{3}^{-}(62 \mathrm{mg} / \mathrm{l}), \mathrm{SO}_{4}{ }^{--}(173 \mathrm{mg} / \mathrm{l}), \mathrm{Cl}^{-}(123 \mathrm{mg} / \mathrm{l})\right]$. This represents critical values that pose risks to the population. An interpretation of graphs of anthropogenic water parameters shows that the primary source of pollution is agricultural activity, which has increased significantly in the study area. However, our investigations and interviews with water resource managers showed that great difficulties persist in the implementation of recommended protective actions.
\end{abstract}

\section{Keywords}

karstic aquifers, anthropogenic pollution, agricultural livestock, Saïda Mountains, physico-chemical characteristics

\section{Introduction}

Numerous authors have studied the nitrate problem with particular attention to its origin and behaviour in groundwater (Didon-Lescot et al., 1998; Compagnon et al., 1997; Louche et al., 1998). To evaluate the vulnerability of groundwater, it is necessary to use chemical data for elements other than nitrates. (Djidi, 1997) used chemical measurement of water sampled from the Saïda groundwater for his interpretations on the double role of water, as chemical and transport agent, through an aquifer. The karstic groundwater of the Saïda Mountains represents a vital resource throughout northwestern Algeria, because of its geographical position and because of the natural wealth (agriculture and mineral waters) it provides. This groundwater is monitored qualitatively and quantitatively at the outlets of the primary springs. The groundwater currently suffers from considerable degradation incurred by the over-exploitation of water and excessive use of agricultural fertilizers. The establishment of protection for this resource should include an evaluation of vulnerable zones and installation of protection zones. Measures to protect the resource in ques-

Corresponding author: Abdelkader Bentabet

a.bentabet@univ-mascara.dz tion require a broad awareness on the part of concerned parties. The purpose of this study was to characterize and provided details on the karstic Saïda Mountains, to analyze the manner in which the degradation affects the water, to specify causes that may lead to this degradation, and to propose adequate strategies to protect the water. The approach is based on three components:

- The first consists of characterizing the physical context of the Saïda Mountains karstic system and evaluating anthropogenic impacts;

- The second involves the use of hydrochemical methods (interpretation of graphs of anthropogenic water parameters) to evaluate the anthropogenic effects on groundwater; and

- The third relates to the awareness of interested parties in the field of agriculture.

\section{Natural specificities}

The ecological diversity of the Saïda Mountains has created a territory rich in waters of varied physicochemical and chemical composition. This area benefits from abundant mineral water reserves and several thermal springs. Geographically speaking, the Saïda region is characterized by two distinct compartments, namely: 


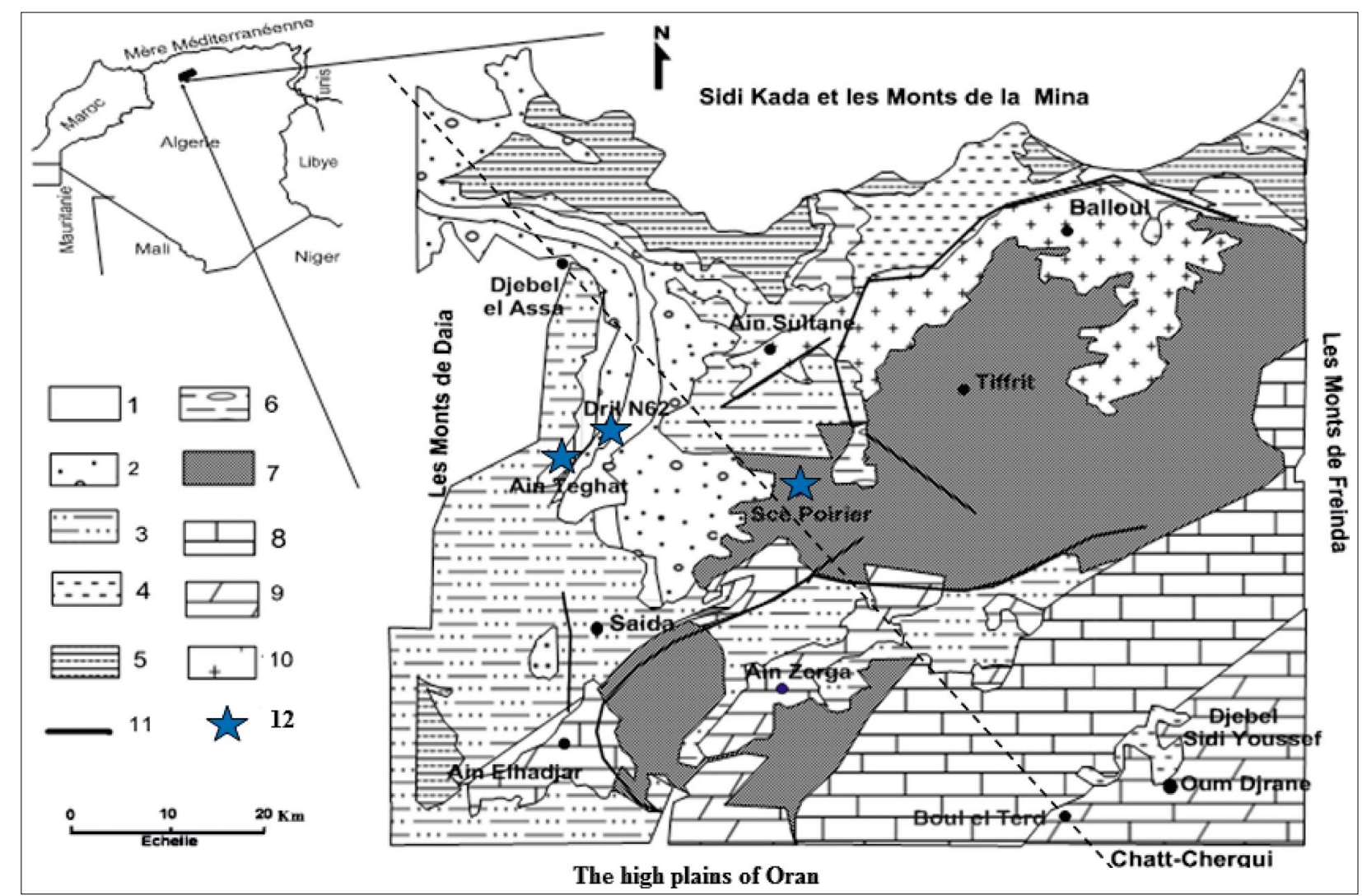

Figure 1: Geographical and geological location of the Saïda Mountains (Pitaud. G, 1973)

1. Quaternary: alluvium, piedmont; 2. Plio-Quaternary: conglomerates and sandstones; 3. Pliocene: conglomerates "Highlands"; 4. Mio-Pliocene: conglomerates and blue marne; 5. Lusitanian: hard sandstone; 6. Callovian-Oxfordian: clayey sandstone,

7. Bajocian-Bathonian: crystalline dolomites and limestones (Zerzour carbonates members); 8. Bajocian: clay and dolomite (Sidi Youcef members); 9. Aalenian: dolomitic limestone (Ain Dez carbonates members, 10. Silurian: metamorfic and eruptique formations; 11. Fault; 12. springs.

a steppe region in the south and a forested mountain region in the north (Agence Nationale des Ressources Hydrauliques) (National Agency of Hydraulic Resources (NAHR), 2015)

\subsection{Geographical location and climate}

The Saïda Mountains are part of the Algerian northwestern high plateaus, bounded to the south by the Oranaise High and to the north by the Sidi Kada and the Mina Mountains, to the west by the Daïa Mountains and to the east by the Frenda Mountains (see Figure 1).

The dominant climate in the region is continental, of semi-arid to arid type. The average rainfall is $400 \mathrm{~mm}$. The annual precipitation is characterized by an extreme irregularity and a low number of rainy days. The average annual temperatures are $23^{\circ} \mathrm{C}$ with minima of $0^{\circ} \mathrm{C}$ and maxima of $35^{\circ} \mathrm{C}$.

\subsection{Geological and Hydrogeological}

Two hydrogeological studies have been conducted in the Saïda Mountains, by (Pitaud, 1973; National Agency of Hydraulic Resources (NAHR), 1982), respectively. These two studies involved the collection of nu- merous geological and hydrogeological data, which now require updating.

According to (Clair, 1952) and (Pitaud, 1973), the general form of the Saïda mountains is a vast anticline of Mesozoic age, mainly represented by the Lower and Middle Jurassic dolomite pinching out the Triassic on the Tiffrit-Ain Soltane Paleozoic diapir. Brittle tectonics have affected these carbonates and resulted in the very specific characteristic structures of the karstic regions. The karstic aquifers have characteristics that distinguish them from other rocks (Bakalowicz, 2005; Figure 1, Figure 2)

These characteristics are: strong heterogeneity with various detritus dimensions, very large emptiness, flow speeds reaching some hundreds of meters per hour, and spring flow that can reach several dozen $\mathrm{m}^{3} / \mathrm{s}$ (Bakalowicz, 2005). The Saïda Mountains contain carbonate rocks of Aalenian-Bajocian-Bathonian age with a water potential ranging from 38 to $50 \mathrm{hm}^{3}$ a year.

\subsection{Economic resources}

The Saïda Mountains have relatively high economic potential, based mainly on agriculture and livestock. Pastoralism is of primary importance, and transhumance 


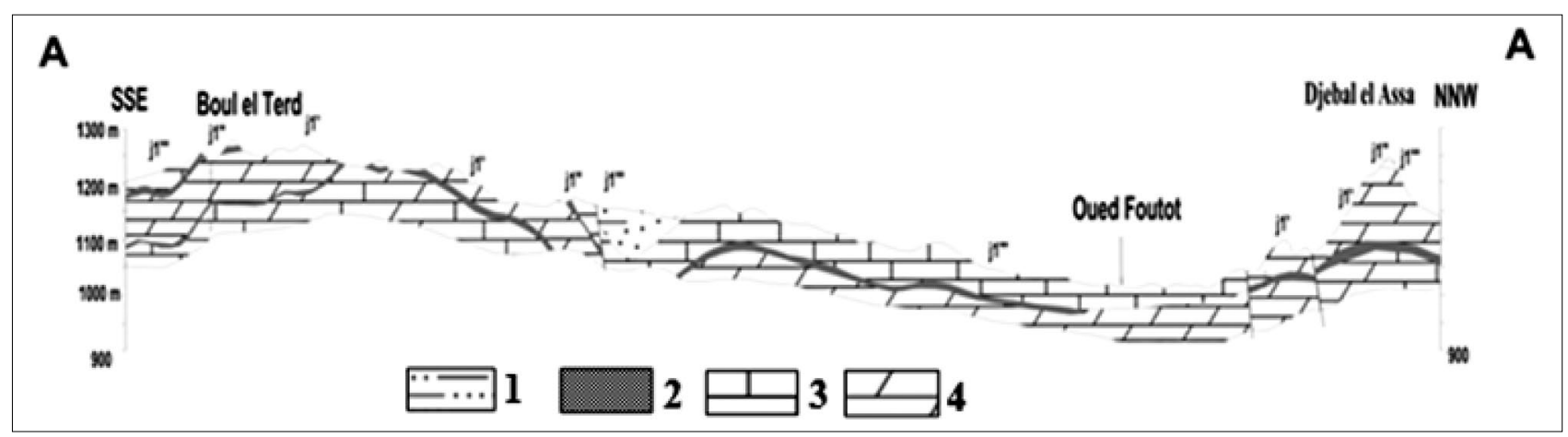

Figure 2: Geological section of the study area (Geological Service of Algeria) (Ganev et al., 1969)

1. Pliocene: conglomerates "Highlands"; 2. Bajocian-Bathonian: crystalline dolomites and limestones (Zerzour carbonates members); 3. Bajocian: clay and dolomite (Sidi Youcef members; 4. Aalenian: dolomitic limestone (Ain Dez carbonates members)

Table 1: Change in the livestock population (Directorate of Agricultural Services of Saïda (DAS), 2014) of Saïda for the years [1991 to 2014].

\begin{tabular}{|l|c|c|c|c|c|c|c|c|}
\hline Year & $\mathbf{1 9 9 1}$ & $\mathbf{1 9 9 2}$ & $\mathbf{1 9 9 3}$ & $\mathbf{1 9 9 4}$ & $\mathbf{1 9 9 5}$ & $\mathbf{1 9 9 6}$ & $\mathbf{1 9 9 7}$ & $\mathbf{2 0 0 0}$ \\
\hline Total head & 811341 & 788019 & 726200 & 703600 & 761700 & 610100 & 615060 & 443570 \\
\hline Year & 2000 & 2001 & 2002 & 2003 & 2004 & 2005 & 2006 & 2007 \\
\hline Total head & 355035 & 420540 & 420540 & 443202 & 620216 & 591220 & 656920 & 622113 \\
\hline Year & 2008 & 2009 & 2010 & 2011 & 2012 & 2013 & 2014 & $/$ \\
\hline Total head & 507120 & 677148 & 704178 & 722494 & 749933 & 892972 & 866090 & $/$ \\
\hline
\end{tabular}

Table 2: Change in agricultural land acreage in (ha) 2000-2015 (DAS)

\begin{tabular}{|l|c|c|c|c|c|c|c|c|}
\hline Year & $\mathbf{2 0 0 0}$ & $\mathbf{2 0 0 1}$ & $\mathbf{2 0 0 2}$ & $\mathbf{2 0 0 3}$ & $\mathbf{2 0 0 4}$ & $\mathbf{2 0 0 5}$ & $\mathbf{2 0 0 6}$ & $\mathbf{2 0 0 7}$ \\
\hline Total Area (ha) & 132946 & 128806 & 121513 & 116599 & 120848.6 & 124153.6 & 122371.1 & 122673.1 \\
\hline Year & 2008 & 2009 & 2010 & 2011 & 2012 & 2013 & 2014 & 2015 \\
\hline Total Area (ha) & 109277.5 & 128722.5 & 129655.5 & 130650.5 & 131821.5 & 133582 & 135137 & 136517 \\
\hline
\end{tabular}

movements are increasing. The area is home to about 805585 sheep and 136517 ha of agricultural land are in production (Direction des Sevices Agricol) (Directorate of Agricultural Services of Saïda (DAS), 2015). Livestock is being raised throughout the Saïda Mountains. The number of livestock increased from 615160 to 866090 head between 1997 and 2014 (see Table 1). During the 2001-2005 period, the region recorded a sharp increase in areas planted in fruit trees and vineyards, from 3276 ha in 2001 to 9500 ha in 2005. At the same time, the surface area occupied by cereals decreased sharply, from 127030 ha in 2001 to 105000 ha in 2005. According to the Ministry of Agriculture, it has committed a large amount of money for agricultural development programs (DAS) (see Table 2). Given the agropastoral vocation of the Saïda Mountains region, the area used for industry is relatively minor. The industrial sector is represented by a few businesses with relatively mild pollution effects, including a cement and plaster factory (El-Hassasna), two brickyards (Sidi Aïssa), agrifood industries in the Saïda industrial zone (dairy production, mineral water, semolina, mills), as well as various industries (textiles in Rebahia and paper bags in Ain El Hadjar).

\section{Agricultural pollution}

The main crops grown in the area are cereals (wheat, barley), which occupy a surface of about 57423 ha; vegetable production that covers a surface approaching 3686 ha; and orchards occupying a surface area of about 136517 ha. Consequently, the various products (phosphates, nitrogen and potash and phytosanitary products) used to increase agricultural output, both qualitative and quantitative, lead to significant pollution risks for groundwater. Fertilizers used to amend the soil easily infiltrate towards the groundwater, thereby risking contamination of this water. The primary fertilizers used in this area are

Table 3: Use of fertilizers by type of dominant speculation in quintals (DAS, 2005) Arboricul (Arboriculture) Viticul

(Viticulture), Vegetab-gar (Vegetable gardening)

\begin{tabular}{|l|c|c|c|c|c|}
\hline \multirow{2}{*}{$\begin{array}{l}\text { Fertilizer } \\
\text { (quintals) }\end{array}$} & \multicolumn{4}{|c|}{ Agriculture } & \multirow{2}{*}{ Arbo- } \\
\cline { 2 - 5 } & $\begin{array}{c}\text { Vicul } \\
\text { riti- }\end{array}$ & cereals & $\begin{array}{c}\text { Vege- } \\
\text { tab-gar }\end{array}$ & \\
\hline Azote & 6608 & 553 & 81500 & 1764 & $\mathbf{9 0 4 2 5}$ \\
\hline Phosphore & 3304 & 474 & 48900 & 1372 & $\mathbf{5 4 0 5 0}$ \\
\hline Potassium & 3304 & 316 & 48900 & 1372 & $\mathbf{5 3 8 9 2}$ \\
\hline
\end{tabular}


ammo-nitrate $\left(\mathrm{NH}_{4}^{+} \mathrm{NO}_{3}^{-}\right)$, potash sulfite $\mathrm{K}_{2} \mathrm{SO}_{4}$ and calcium nitrate $\mathrm{Ca}\left(\mathrm{NO}_{3}^{-}\right)_{2}$. The quantities of fertilizers used are shown in the table below (see Table 3).

\section{Materials and methods}

The four main representative karst systems of the Saïda Mountains are: Ain Zerga spring, Drilling N62, Ain Teghat spring, and Poirier spring. These water points were sampled quarterly during the 2004-2007 period and monthly during 2014 . The physical parameters (electric conductivity, temperature and $\mathrm{pH}$ ) were measured in situ. Other parameters and elements (Turbidity, $\mathrm{RS}, \mathrm{Ca}^{2+}, \mathrm{Mg}^{2+}, \mathrm{Na}^{+}, \mathrm{K}^{+}, \mathrm{NH}_{4}^{+}, \mathrm{HCO}_{3}^{-}, \mathrm{Cl}^{-}, \mathrm{SO}_{4}{ }^{2-}$ , $\mathrm{NO}_{3}^{-}, \mathrm{PO}_{4}{ }^{2+}$ ) were analyzed at the NAHR Oran laboratory using the following methods:

- Volumetric dosing for: $\mathrm{Ca}^{2+}, \mathrm{Mg}^{2+}, \mathrm{HCO}_{3}^{-}, \mathrm{Cl}^{-}$.

- Spectrophotometer for: $\mathrm{SO}_{4}{ }^{2-}$ and $\mathrm{NO}_{3}{ }^{-}$.

- Flame spectrophotometer for: $\mathrm{Na}^{+}, \mathrm{K}^{+}$.

\section{Results}

The karstic rocks of the Saïda Mountains are covered by a relatively thin layer of soil, which facilitates the transmission of fertilizer towards ground waters through the unsaturated zone (Canter, 2019; Larocque and Banton, 1995; Smith et al., 1999). This karstification allows direct contact between the atmosphere and groundwater, and any temperature change automatically influences the variability of groundwater temperature $\left(14\right.$ to $\left.23^{\circ} \mathrm{C}\right)$. The $\mathrm{pH}$ is slightly basic (7.1 to 8.1$)$ and conductivity ranges from 550 to $995 \mu \mathrm{s} / \mathrm{cm}$, indicating increasing mineralization.

Interpretation of the Piper diagram results (see Figure 3) indicates that the water of the Saïda Mountains is generally collecting calcium bicarbonate and magne-

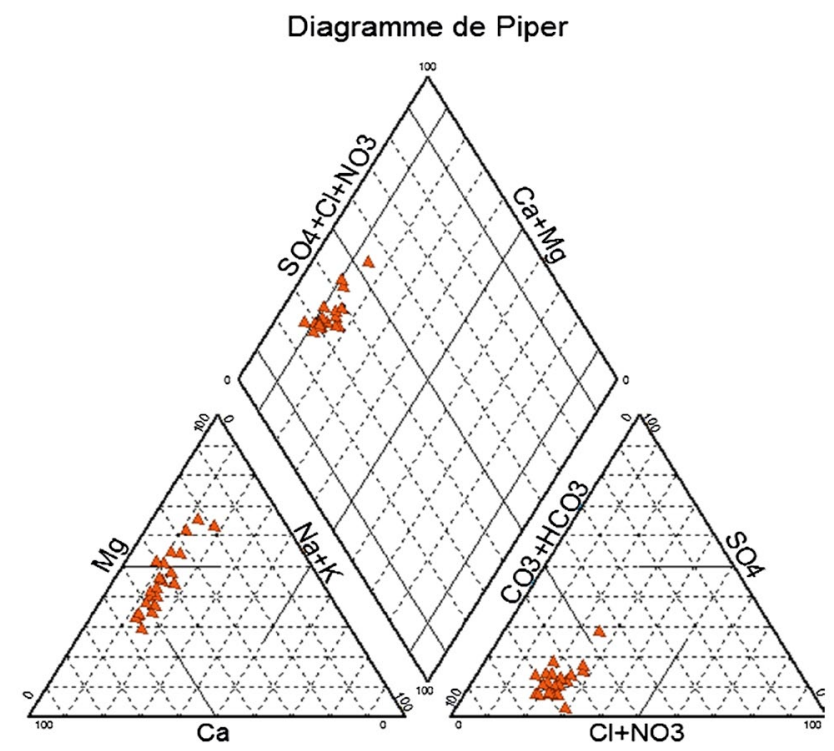

Figure 3: The waters chemical facies of the Saïda Mountains
Table 4: Chemical standards of potability for major ions $(\mathrm{mg} / \mathrm{l})$ Water of the karstic aquifer of the Saïda Mountains, Permissible; Accep: acceptable; Aver: Average concentrations; Min: minimal; Max: maximal.

\begin{tabular}{|l|c|c|c|c|c|}
\hline \multirow{2}{*}{ Variable } & \multicolumn{2}{|c|}{$\begin{array}{c}\text { Values } \\
\text { (W.H.O) }\end{array}$} & \multicolumn{3}{c|}{$\begin{array}{c}\text { Values in the aquifer of } \\
\text { the Mountains of Saïda }\end{array}$} \\
\cline { 2 - 6 } & Permissible & Accep & Aver & Min & Max \\
\hline $\begin{array}{l}\text { Cond } \\
(\mu \mathrm{s} / \mathrm{cm})\end{array}$ & 2000 & 400 & 757.5 & 551 & 993 \\
\hline $\mathrm{T}\left({ }^{\circ} \mathrm{c}\right)$ & 25 & 15 & 19.2 & 14 & 23 \\
\hline $\mathrm{pH}$ & 9.5 & 6.5 & 7.3 & 7.6 & 8.1 \\
\hline $\mathrm{Ca}^{2+}$ & 100 & - & 66.9 & 33 & 104 \\
\hline $\mathrm{Mg}^{2+}$ & 50 & 30 & 51 & 31 & 76 \\
\hline $\mathrm{Na}^{+}$ & 100 & $<20$ & 28.8 & 12 & 58 \\
\hline $\mathrm{K}^{+}$ & 12 & $<10$ & 1.7 & 1 & 5 \\
\hline $\mathrm{SO}_{4}^{2-}$ & 400 & 200 & 54.4 & 12 & 173 \\
\hline $\mathrm{Cl}^{-}$ & 600 & 250 & 54.2 & 27 & 123 \\
\hline $\mathrm{HCO}_{3}^{+}$ & - & - & 342.3 & 176 & 444 \\
\hline $\mathrm{NO}_{3}^{-}$ & 50 & 45 & 32.9 & 15 & 62 \\
\hline $\mathrm{NO}_{2}^{-}$ & 0.1 & 0 & 0 & 0 & 0.2 \\
\hline
\end{tabular}

sium, with portions of nitrate, sulfate, and chloride. This tendency is linked to anthropogenic agricultural pollution (e.g., Kopić et al., 2016; Mirčovski et al., 2018).

The comparison of physico-chemical concentrations with standards (World Health Organization, 1986) shows that the maximum levels $\left(\mathrm{NO}_{3}{ }^{-}=62 \mathrm{mg} / 1, \mathrm{NO}_{2}{ }^{-}\right.$ $=0.2 \mathrm{mg} / 1$ and $\mathrm{EC}=993)$ exceed acceptable levels. (see Table 4).

The water ranges from average to highly mineralized. The average of total dissolved solids is about 6.9 $\mathrm{mg} / \mathrm{l}$. Electric conductivity values range between 551 and $993 \mu \mathrm{Scm}^{-1}$. The increase in electrical conductivity shows a salt contribution from soil leaching during rainfall infiltration and remobilization of salt stored in sediments. Nitrates generally come from the mineralization of organic waste (Schenck, 1991) and artificial fertilizers. Organic matter is mineralized through the biological oxidation of ammonium $\left(\mathrm{NH}_{4}^{-}\right)$to $\mathrm{NO}_{3}$ (Canter, 2019). The successive transformations made by chemoautotrophic bacteria are the following:

- $\mathrm{NH}_{4}^{+}+3 / 2 \mathrm{O}_{2}$ àNO${ }_{2}^{-}+2 \mathrm{H}^{+}+\mathrm{H}_{2} \mathrm{O}$ (by bacteria of the Nitrosomonas family)

- $\mathrm{NO}_{2}^{-}+1 / 2 \mathrm{O}_{2}$ à $\mathrm{NO}_{3}^{-}$(by bacteria of the Nitrobacter family).

Anthropogenic groundwater pollution varies according to agricultural activity and according to weather conditions. The monitoring over time of anthropogenic elements within the four karst systems during the 2004-2014 period has shown the following relatively high concentrations: sulfates $(173 \mathrm{mg} / \mathrm{l})$, nitrates (58 $\mathrm{mg} / \mathrm{l})$ and chlorides (123 mg/l). 


\subsection{Nitrate pollution}

The nitrate concentration present in the aquifer water suggests a large pollution source (Dillaha, 1989; Kowal and Polik, 1987). Nitrate concentrations increased as agricultural and livestock activity increased. In 2004, the

Table 5: Nitrate variations (mg/l) at four sites marked at the Figure 1

\begin{tabular}{|l|c|c|c|c|}
\hline Date & Well N62 & Ain Zerga & Poirier & Ain Teghat \\
\hline $24 / 08 / 2004$ & 21 & 24 & $/$ & $/$ \\
\hline $21 / 12 / 2004$ & 21 & 24 & $/$ & $/$ \\
\hline $21 / 03 / 2005$ & 15 & 22 & $/$ & $/$ \\
\hline $20 / 06 / 2005$ & 20 & 21 & $/$ & $/$ \\
\hline $25 / 09 / 2005$ & 26 & 25 & $/$ & $/$ \\
\hline $18 / 12 / 2005$ & 20 & 30 & $/$ & $/$ \\
\hline $19 / 03 / 2006$ & 25 & 16 & $/$ & $/$ \\
\hline $20 / 06 / 2006$ & 25 & 41 & $/$ & $/$ \\
\hline $31 / 10 / 2006$ & 23 & 38 & $/$ & $/$ \\
\hline $26 / 12 / 2006$ & 30 & 32 & $/$ & $/$ \\
\hline $20 / 02 / 2007$ & 26 & 29 & $/$ & $/$ \\
\hline $28 / 01 / 2014$ & 37 & 37 & 58 & 35 \\
\hline $04 / 03 / 2014$ & 33 & 25 & 27 & 53 \\
\hline $30 / 03 / 2014$ & 33 & 41 & 35 & 55 \\
\hline $07 / 05 / 2014$ & 35 & 39 & 35 & 59 \\
\hline $12 / 06 / 2014$ & 33 & 38 & 36 & 58 \\
\hline $16 / 07 / 2014$ & 36 & 40 & 37 & 59 \\
\hline $19 / 08 / 2014$ & 36 & 39 & 36 & 60 \\
\hline $24 / 09 / 2014$ & 35 & 37 & 33 & 58 \\
\hline $17 / 11 / 2014$ & 38 & 34 & 35 & 57 \\
\hline $20 / 12 / 2014$ & 39 & 35 & 35 & 59 \\
\hline $28 / 01 / 2015$ & 38 & 30 & 34 & 62 \\
\hline
\end{tabular}

annual nitrate average reached $22.5 \mathrm{mg} / \mathrm{l}$; during that year agricultural surface area was estimated at 120599 ha and the livestock population was of the order of 620216 head. In 2014, the nitrate average had increased to $41 \mathrm{mg} / \mathrm{l}$. The nitrate increase is related to agricultural development (135000 ha) and the increase in the number of livestock 866090 head (see Table 5).

Nitrate concentrations increased in the early 2000s. This increase resulted from agricultural development in the region. We see a good agreement between the rise in nitrate content and the increases in agricultural surface area and the livestock population (see Figure 4).

In our study area, where the climate is semi-arid, the variation of agricultural activity is influenced by rainfall. The average nitrate content in the irrigated perimeters areas reached relatively high concentrations $(56 \mathrm{mg} / \mathrm{l})$, whereas, in non-irrigated perimeters the average was 36 $\mathrm{mg} / \mathrm{l}$ (see Figure 5).

This increase in the nitrate concentrations suggests that the groundwater pollution is relatively recent. $\mathrm{Ni}$ trate concentrations during (2004-2007) ranged from 15 to $41 \mathrm{mg} / \mathrm{l}$; however, in 2014 , the average of this element reached 41mg/l. Between 2007 and 2014 nitrates increased about $2.14 \mathrm{mg} / 1$ per year. The nitrate average of the Tehgat Spring reached $56 \mathrm{mg} / \mathrm{l}$ in 2014 due to relatively high levels of agricultural activity and animal breeding. Nitrate pollution can cause pathologies in animals and human beings, particularly methemoglobinemia in babies and cancer in adults (Thamke et al., 1998; Davison et al., 1964; Davison et al., 1965; Comly, 1945; Lijinski and Epstein, 1970). In 1992, nitrate concentrations ranged between 5 and $8 \mathrm{mg} / 1$ (NAHR, 1992) at a time when livestock numbered 788019 head, and agricultural production was low. Since the year 2000, when the state began to subsidize agricultural development, nitrate concentrations have increased to relatively high values (22.5 mg/l in 2004) (28.8 mg/l in 2006) and

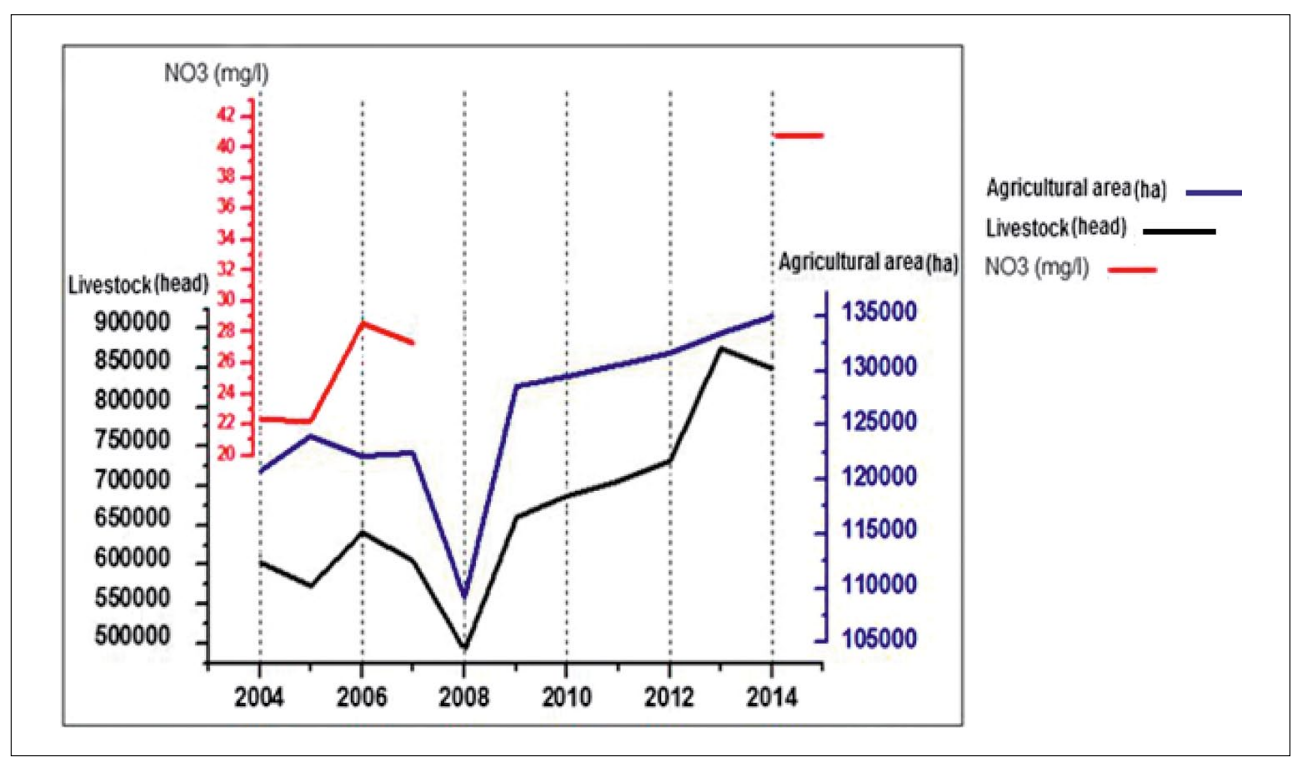

Figure 4: The relationship between nitrate variations and agricultural activity (2004 - 2014) 


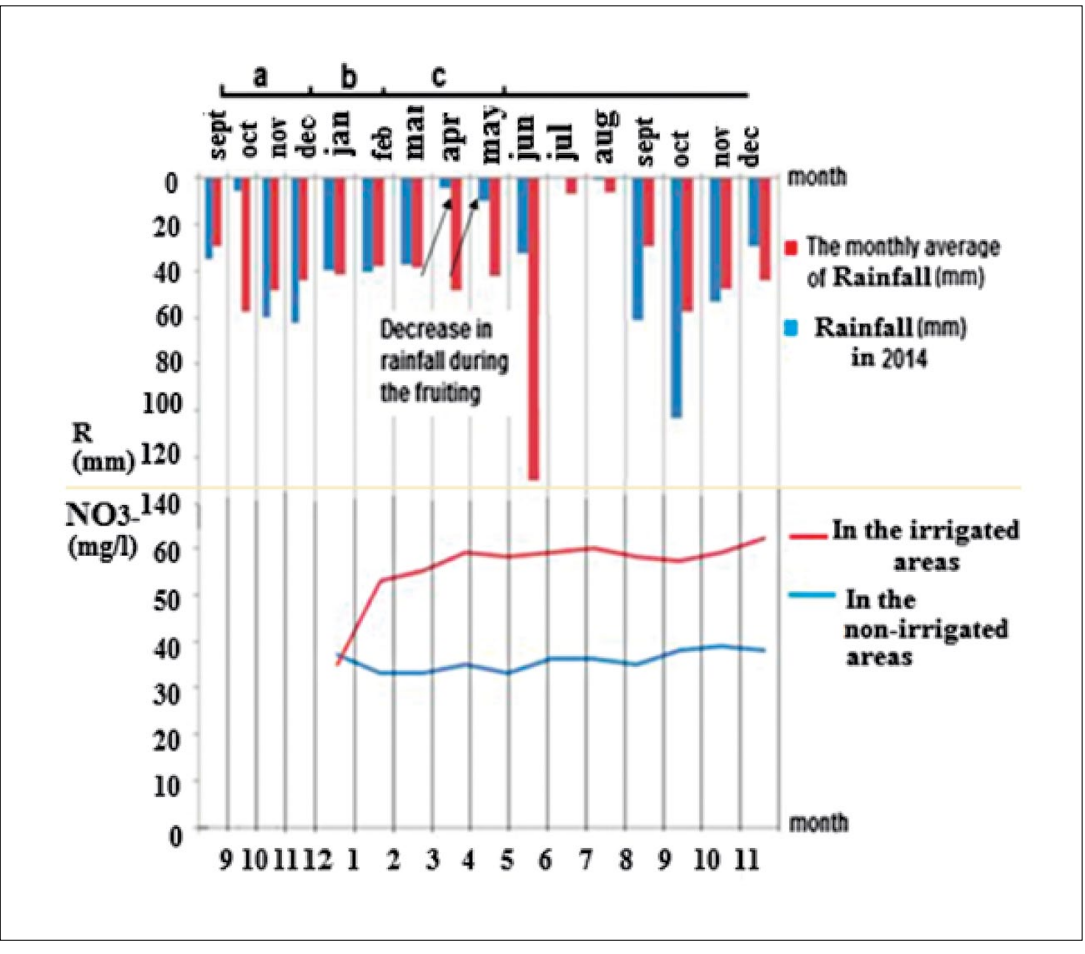

Figure 5: Nitrate levels variation in the irrigated perimeters and the non-irrigated perimeters as a function of rainfall

(September 20014 - November 2015).

$\mathrm{a}=$ sowing time. $\mathrm{b}=$ application period of chemical and organic fertilizers. $\mathrm{c}=$ phytosanitary period of treatment during fructification of the plant.

Table 6: Changes in nitrate levels, livestock and agricultural area

\begin{tabular}{|l|c|c|c|c|c|c|c|c|c|c|c|}
\cline { 2 - 13 } \multicolumn{1}{c|}{} & \multicolumn{6}{|c|}{ The State subsidy Period for The Agricultural Development } & $\mathbf{2 0 0 7}$ \\
\hline Dates & $\mathbf{1 9 9 2}$ & $\mathbf{1 9 9 3}$ & $\mathbf{1 9 9 4}$ & $\mathbf{2 0 0 0}$ & $\mathbf{2 0 0 1}$ & $\mathbf{2 0 0 4}$ & $\mathbf{2 0 0 5}$ & $\mathbf{2 0 0 6}$ & $\mathbf{2 0 0 7}$ & $\mathbf{2 0 1 4}$ & $\mathbf{2 0 1 5}$ \\
\hline $\mathrm{NO}_{3}^{-}(\mathrm{mg} / \mathrm{l})$ & $5-8$ & & & & & 22.5 & 22.4 & 28.8 & 27.5 & 41.02 & 41 \\
\hline $\begin{array}{l}\text { Livestock } \\
\text { (head) }\end{array}$ & 788019 & 726200 & 703600 & 443570 & 355035 & 620216 & 591220 & 656920 & 622113 & 866090 & \\
\hline $\begin{array}{l}\text { agricultural surface } \\
\text { area } \\
\text { (ha) }\end{array}$ & \multicolumn{3}{|c|}{$\begin{array}{c}\text { Low agricultural } \\
\text { cultivation }\end{array}$} & $\begin{array}{l}\text { Start of } \\
\text { subsidized } \\
\text { agriculture }\end{array}$ & 120848 & 124153 & 122673 & 122673 & 135137 & 130453 \\
\hline
\end{tabular}

(41mg/l in 2014) as the agricultural area increased. At the same time, the livestock population remained similar to those of the 1990s (see Table 6). To determine whether agricultural or breeding activities had more impact on increased nitrate concentrations, the years between 1992 and 2014 have been selected. It was noticed that the years 1992 and 2014 had similar numbers of livestock (788019 and 866090 head) but: (a) agricultural crops increased from a small area (less than 5000 ha) in 1992 to 135137 ha in 2014 , (b) nitrate concentrations increased from $5 \mathrm{mg} / 1$ in 1992 to $41 \mathrm{mg} / 1$ in 2014. So, the agricultural crops had a major influence on increased nitrate concentrations in the karstic aquifer.

\subsection{Sulfate pollution}

Sulfate is generally released from phytosanitary products (Gril et al., 2011). The use of sulfur for the protection of vineyards and for vegetable crops, such as to protect tomatoes from mildew, and the use of potash slag and phosphates as fertilizer can generate high quantities of sulfates. The average concentration of this constituent reached relatively high values during the years 20042007 (84.1 mg/l). In 2014, sulfate concentrations decreased by half $(43 \mathrm{mg} / \mathrm{l})$. The drop in sulfates in that year may be explained by the reduction in fruit production due to the lack of rain, particularly for the months of April $(5 \mathrm{~mm})$ and May $(10 \mathrm{~mm})$, which is the fruit production period. Even so, sulfate concentrations in irrigated zones (Ain Teghat) remained high $(61 \mathrm{mg} / \mathrm{l})$. The variations in sulfate contents show that sulfate pollution is linked to agricultural activity (see Table 7, Figure 8).

\subsection{Chlorine pollution}

The excessive use of phytosanitary products in agriculture has caused severe groundwater pollution in recent years. Table 8 shows a rather high chlorine concentration $(123 \mathrm{mg} / \mathrm{l}$ and $90 \mathrm{mg} / \mathrm{l})$ for the period from 2004 to 2006. These concentrations decreased during 2014 (from $85 \mathrm{mg} / 1$ to $62 \mathrm{mg} / \mathrm{l}$ ). Similar to the behavior of sulfates, the chloride concentrations followed the same pattern as sulfates, a pattern that is linked to the intensity of agricultural activity, as explained previously. 
Figure 6: Sulfate levels variation in the irrigated perimeters and the non-irrigated perimeters as a function of rainfall

(September 20014 - November 2015).

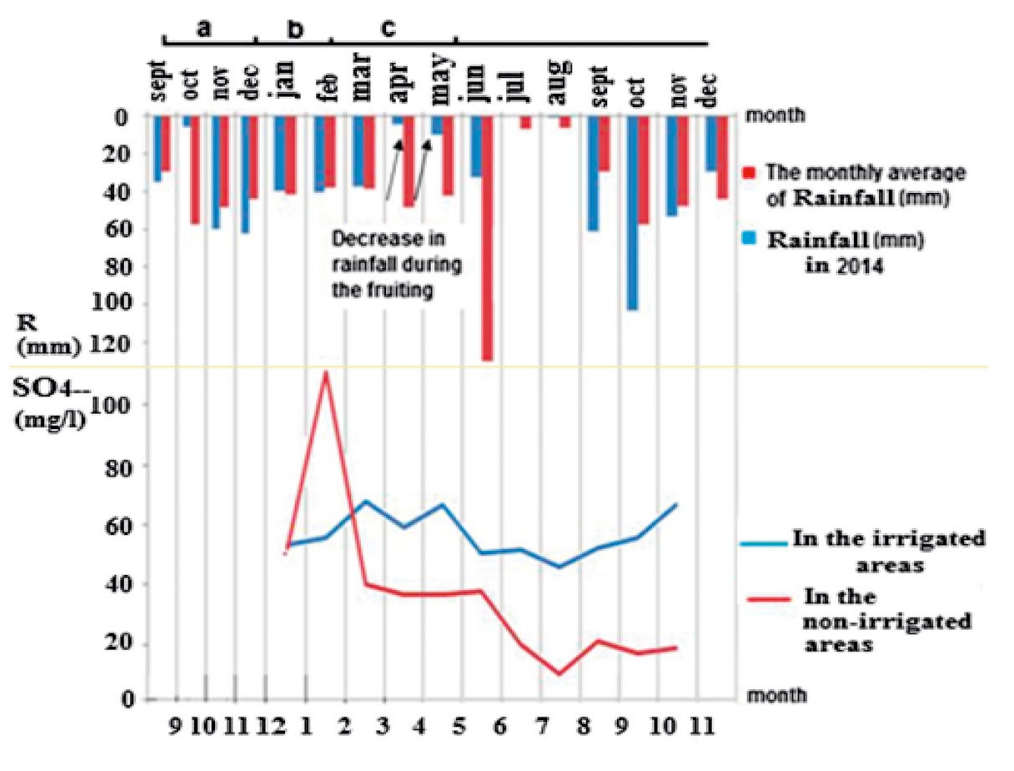

Table 7: Sulfate content (mg/l) period 2004-2014 at four sites marked in Figure 1

\begin{tabular}{|l|c|c|c|c|}
\hline Date & Well N62 & Ain Zerga & Poirier & Ain Teghat \\
\hline $24 / 08 / 2004$ & 72 & 68 & $/$ & $/$ \\
\hline $21 / 12 / 2004$ & 72 & 12 & $/$ & $/$ \\
\hline $21 / 03 / 2005$ & 96 & 76 & $/$ & $/$ \\
\hline $20 / 06 / 2005$ & 75 & 72 & $/$ & $/$ \\
\hline $25 / 09 / 2005$ & 173 & 62 & $/$ & $/$ \\
\hline $18 / 12 / 2005$ & 67 & 93 & $/$ & $/$ \\
\hline $19 / 03 / 2006$ & 12 & 66 & $/$ & $/$ \\
\hline $20 / 06 / 2006$ & 35 & 50 & $/$ & $/$ \\
\hline $31 / 10 / 2006$ & 90 & 55 & $/$ & $/$ \\
\hline $26 / 12 / 2006$ & 89 & 50 & $/$ & $/$ \\
\hline $20 / 02 / 2007$ & 144 & 46 & $/$ & $/$ \\
\hline $28 / 01 / 2014$ & 31 & 27 & 57 & 58 \\
\hline $04 / 03 / 2014$ & 44 & 53 & 110 & 60 \\
\hline $30 / 03 / 2014$ & 48 & 57 & 46 & 71 \\
\hline $07 / 05 / 2014$ & 46 & 43 & 43 & 63 \\
\hline $12 / 06 / 2014$ & 61 & 40 & 43 & 70 \\
\hline $16 / 07 / 2014$ & 38 & 29 & 44 & 55 \\
\hline $19 / 08 / 2014$ & 40 & 31 & 28 & 56 \\
\hline $24 / 09 / 2014$ & 40 & 30 & 19 & 51 \\
\hline $17 / 11 / 2014$ & 40 & 30 & 29 & 57 \\
\hline $20 / 12 / 2014$ & 40 & 32 & 25 & 60 \\
\hline $28 / 01 / 2015$ & 45 & 34 & 27 & 70 \\
\hline
\end{tabular}

\section{Recommendations}

The rules resting on the laws regulating the use of fertilizers in zones identified as vulnerable such as our region are:
- The excessive use of fertilizer increases the expenses of the farmer on one hand, and increases the nitrate contents in the groundwater.

- The reduction of the dosage rate per hectare for fertilizers can minimize expenses and decrease the concentration of nitrate in groundwater;

- The creation of pilot farms acting as a reference for farmers;

- Avoid standard irrigation systems (surface flooding and furrow irrigation), by introducing more recent systems such as localized systems and sprinkler irrigation to control the rates of fertilizer use.

- After any cultivation, fallow land (farmlands without vegetation cover) should be avoided. The permanent covering of the ground by vegetation, not requiring any fertilizer, or by crop residue is more effective on the lowering of nitrates.

\section{Conclusion}

This study found that the content of anthropogenic elements in the karstic aquifer appears to increase with time. Generally, the elements encountered are of agricultural origin. We also noticed that there is a clear relationship between water pollution and the increase in agricultural area and the number of livestock.

The Saida Mountains have high agricultural potential, due to their abundant water resources. As agricultural activity increases, anthropogenic impacts multiply, and they represent the primary source of groundwater degradation. The interpretation of the results obtained by the hydrochemical study allows us to conclude that the waters of the karstic groundwater of Saïda Mountains are threatened. 
Analytical results showing concentrations of nitrate $(60 \mathrm{mg} / \mathrm{l})$, chloride $(123 \mathrm{mg} / \mathrm{l})$, and sulfate $(173 \mathrm{mg} / \mathrm{l})$ highlight the extent of anthropogenic pollution of the karstic groundwater. Nitrates increased about $2,14 \mathrm{mg} / \mathrm{l}$ per year (between 2007 and 2014). Fertilizers and phytosanitary products used in agriculture are the primary source of groundwater pollution, particularly when these substances are applied to the land (open land, fallow land) outside of the vegetation period. Sustainable protection of this groundwater is relatively difficult, but is still possible if we apply measures better adapted to the real dangers, if the protection engages all stakeholders involved in groundwater management, and if the protection program addresses environmental interactions.

\section{References}

Agence Nationale des Ressources Hydrauliques. (1973): Système d'Information National (National Information System). Journal de l'Agence Nationale des Ressources Hydrauliques en Algerie, 6, 22-45. (in French)

Bakalowicz, M. (2005): Karst groundwater: A challenge for new resources. Hydrogeology Journal,13, 1, 148-160.

Canter, L. W. (2019): Fundamental Aspects of Nitrates in Groundwater. Lewis publishers, 1-18.

Clair, A. (1952): Etude Hydrogeologique des Monts De Saida (Hydrogeological study of the Saida Mountains). Paris Presse Universitaire; France (Paris University Press; France). 10-12 (in French)

Comly, H. H. (1945): Cyanosis In Infants Caused By Nitrates In Well Water. Journal of the American Medical Association, 129, 2, 112.

Compagnon, F., Guglielmi, Y., Mudry, J., Follacci, J., Ivaldi, J. (1997): Approche chimique et isotopique de lorigine des eaux en transit dans un grand mouvement de terrain: Exemple du glissement de La Clapière (Alpes-Maritimes, France) (Chemical and isotopic approach to the origin of water in transit in a large movement of ground: Example of the sliding of La Clapière (Alpes-Maritimes, France)). Comptes Rendus De LAcadémie Des Sciences - Series IIA - Earth and Planetary Science,325, 8, 565-570. (in French)

Davison, K., Hansel, W., Krook, L., Mcentee, K., Wright, M. (1964): Nitrate Toxicity in Dairy Heifers. I. Effects on Reproduction, Growth, Lactation, and Vitamin A Nutrition. Journal of Dairy Science,47, 10, 1065-1073.

Davison, K., Mcentee, K., Wright, M. (1965): Responses in Pregnant Ewes Fed Forages Containing Various Levels of Nitrate. Journal of Dairy Science,48, 7, 968-977.

Directorate of Agricultural Services of Saïda, Algeria (DAS). (2015): Des données de base sur l'agriculture de la zone de Saïda (Basic data on agriculture in the Saida region). (in French)

Didon-Lescot, J., Guillet, B., Lelong, F. (1998): Le nitrate des ruisseaux, indicateur de l'état sanitaire et des perturbations de lécosytème forestier. Exemple du Mont Lozère (Nitrate of creeks, indicator of the health status and disturbances of the forest ecosystem. Example of Mont Lozère). Comptes
Rendus De LAcadémie Des Sciences - Series IIA - Earth and Planetary Science, 327, 2, 107-113. (in French)

Dillaha, T. (1989): Effects of conservation tillage on groundwater quality - Nitrates and pesticides. Agriculture, Ecosystems \& Environment, 26, 2, 150-151.

Djidi, K. (1997): Apport des Systemes d'Informations Geographiques a la determination des zones a risques de pollution des ressources en eau (Contribution of Geographical Information Systems to the determination of areas at risk of pollution of water resources). Thèse de maitrise en techniques spatiales, Centre National des Techniques Spatial d'Oran (Master's thesis in space techniques, National Center for Space Technology of Oran). 120-130 (in French)

Ganev, M., Khistchev, K., Kolev, J., Moev, M. (1969): carte de la coupe géologique de Saîda, Algérie (Map of the geological section of Saîda). Service Géologique de l'Algérie. (in French)

Gril, J., Carluer, N., Hénaff, G. L. (2011): Des zones tampons pour limiter la pollution des eaux par les pesticides dans les bassins versants (Buffer zones to limit water pollution by pesticides in watersheds). Techniques Sciences Méthodes, 7/8, 20-32. (in French)

Kopić, J., Loborec, J., Nakić, Z. (2016): Hydrogeological And Hydrogeochemical Characteristics Of A Wider Area Of The Regional Well Field Eastern Slavonia - Sikirevci. The Mining-Geological-Petroleum Engineering Bulletin (Rudarsko-geološko-naftni zbornik),31, 1, 47-66.

Kowal, A. L., Polik, A. (1987): Nitrates in Groundwater. Environmental Technology, In: De Waal KJA, Van Den Brink WJ. Environmental technology, proceedings of the second European conference on environmental technology, Amsterdam, The Netherlands, Springer Netherlands, Dordrecht, pp. 604-609.

Larocque, M., Banton, O. (1995): Gestion de la contamination des eaux souterraines par les fertilisants agricoles: Application du modèle AgriFlux (Management of groundwater contamination by agricultural fertilizers: Application of the Agriflux model). Revue Des Sciences De Leau,8, 1, 3. (in French)

Lijinsky, W., Epstein, S. S. (1970): Nitrosamines as Environmental Carcinogens. Nature, 225, 5227, 21-23.

Louche, B., Crampon, N., Bracq, P. (1998): Qualité et comportement de laquifère crayeux sur le littoral Nord-Pas-deCalais (Quality and behavior of chalky lacquer on the Nord-Pas-de-Calais coast). Comptes Rendus De LAcadémie Des Sciences - Series IIA - Earth and Planetary Science, 327, 7, 463-470. (in French)

Mirčovski, V., Gičevski, B., Dimov, G. (2018): Hydrochemical Characteristics Of The Groundwaters In Prilep'S Part Of Pelagonia Valley - Republic Of Macedonia. Rudarskogeološko-naftni Zbornik,33, 3, 111-119.

Pitaud, G. (1973): Carte géologique des Monts de Saida (Geological map of the Saida Mountains). Agence National des Ressources Hydraulique Oran -Algérie. (in French)

Pitaud, G. (1973): Etude hydrogéologique pour la mise en valeur de la vallée d'oued de Saïda (Hydrogeological study for the development of the valley of Wadi Saïla). Paris 
Presse Universitaire France (Paris University Press France). 213, 17-25. (in French)

Schenck, Ch. (1991): L'azote: nécessité, risques et remèdes (Nitrogen: necessity, risks and remedies). APRIA, Annales du Colloque sur 1'Azote. Paris, France, 213 p. (in French)
Smith, G. D., Wetselaar, R., Fox, J. J., Robert H. M. Van De Graaff, Moeljohardjo, D., Sarwono, J., Basuki. (1999): The origin and distribution of nitrate in groundwater from village wells in Kotagede, Yogyakarta, Indonesia. Hydrogeology Journal,7, 6, 576-589.

\section{SAŽETAK}

\section{Utjecaj razvoja poljoprivrede na krške podzemne vode planina Saïda u Alžiru}

Kvaliteta vode od velike je važnosti za javno zdravstvo te ovaj rad prikazuje praćenje kvalitete podzemnih voda u odabranome području u Alžiru. Dobro upravljanje vodnim resursima ovisi o nizu kvalitativnih mjera te određivanju uzroka zagađenja (poljoprivreda), mjerenju kvalitete i predviđanju ponašanja vodonosnika tijekom dužega razdoblja. U radu se utvrđuju kemijski facijesi, podrijetlo i kvaliteta vode u krškim vodonosnicima planina Saïda u Alžiru. Te planine sastoje se od karbonatnih masiva (vapnenačko-dolomitne stijene) ranoga i srednjega jurskog doba. Vodonosnik planina Saïda napaja se oborinama i relativno gustim privremenim hidrografskim sustavom. Planine su važan vodonosnik sjeverozapadnoga Alžira. Antropogeni utjecaji neprestano mijenjaju fizičko-kemijska svojstva vode u njemu. Koncentracije antropogenih parametara [ $\left.\mathrm{NO}_{3}^{-}(62 \mathrm{mg} / \mathrm{l}), \mathrm{SO}_{4}^{2-}(173 \mathrm{mg} / \mathrm{l}), \mathrm{Cl}^{-}(123 \mathrm{mg} / \mathrm{l})\right]$ u mjernim točkama dostižu kritične vrijednosti rizične za stanovništvo. Interpretacija grafikona antropogenih parametara vode pokazuje kako je primarni izvor onečišćenja poljoprivredna djelatnost, koja se znatno povećala na istraživanome području. Međutim, naša istraživanja i razgovori s voditeljima vodnih resursa pokazuju da i dalje postoje velike poteškoće u provedbi preporučenih zaštitnih mjera.

\section{Ključne riječi:}

krški vodonosnici, antropogeno zagađenje, stoka, planine Saïda, fizičko-kemijska svojstva

\section{Authors contributions}

Abdelkader Bentabet and Christophe Emblanch: conceived the presented idea, evolved overarching research goals and aims. Abdelkader Bentabet and Benyakhelef Benamina: acquisition of data, conducted research and investigation process. Abdelkader Bentabet: (a) analysis and interpretation of data (solely) and (b) wrote the manuscript with support from Habib Azzaz and Christophe Emblanch. Habib Azzaz: critical revision. Habib Azzaz and Christophe Emblanch: these authors contributed to the final version of the manuscript. 